\title{
On-Line Destination Branding: An Investigation Into The Divergence Between Brand Goals And On-Line Implementation
}

Jens Blumrodt, ESC Rennes School of Business, France Adrian Palmer, ESC Rennes School of Business, France

\begin{abstract}
The marketing of tourism destinations has become increasingly competitive. However, a tourism destination cannot be seen as a single destination-based entity competing with other destinations. Each tourism destination manager must typically integrate a network of interested stakeholders and mediate between political aims and operational realities. Websites are an increasingly important focus for competitive differentiation of tourism destinations. This research examines the effects of cultural differences on website development by comparing cultural environments typified by a prevalence of "collectivism" with those typified by "individualism". Websites from a sample of French and English seaside tourism destinations are compared, with a focus on tourism destination brand image elements. Our approach combines two methods. First, we analyse specific communicated images. Second, interviews with officials of these cities are undertaken to compare the communicated image to the desired one. We find that cities with a similar environment communicate elements of their natural settings as well as other brand elements, but the communicated image often does not correspond to the desired brand image. Therefore we propose a model to promote the desired destination brand image.
\end{abstract}

Keywords: Destination Branding; E-Marketing; Brand Image; Tourism Marketing

\section{INTRODUCTION}



he concept of place branding is not new, but the internet has opened new possibilities for segmenting audiences and promoting differentiated brand propositions to different targeted segments. However, tourism destination brands remain more problematic than more conventional product brands because of the need to satisfy multiple stakeholders' interests, typically local residents and business interests, and the tourists themselves. Furthermore, the tourism destination "product" is typically not under the direct control of one body and therefore brand development must rely on persuasion and the integration of diverse stakeholders' interests rather than the control of a single authority over the brand position. A consequence of diverse control and interest groups is the observation that the brand position for a destination as sought by the dominant group of stakeholders may diverge from the brand position that is actually communicated through a destination's website. In this study, we investigate the causes and consequences of divergence between a destination's desired and actual image portrayed through on-line media.

\section{CONCEPTUAL DEVELOPMENT}

The growing importance of the Internet on tourism destination communication is now quite apparent as tourism destinations small and large expose their websites to potential tourists. Place branding is for these cities an important marketing tool. Generic branding models and tourism segmentation models led our investigation to compare city branding "as officials wish that it to be" with "how it actually is". 
Place branding is becoming more popular and marketing strategies are shifting to strategic place/destination brand management. City brand rankings ( $c f$. Anholt-GMI City Brands Index [in Anholt, 2006] or the Saffron European City Brand Barometer demonstrate the importance given to city branding. While the need for place/destination branding is widely recognised, there is nevertheless confusion about its nature and scope (Anholt, 2010). There is very little common theory to reflect "what" is being done. Research and other contributions have instead tended to focus on the methods of branding, in other words, "how" it is done. The latter is also linked to diversity of perceptions due to the variety of target groups (Zenker, 2011).

The form and content of websites contain brand association categories. Compared to previous research we "catch" the communicated image and compare these elements to the desired image expressed by officials and elected members responsible for developing tourism policy in a destination. The study's objectives focus on the destinations' principal websites. It is recognised that tourism destinations often have multiple websites targeting different market segments. The tourism offices nevertheless generally have one principal "homepage" website. This website functions as a communication tool and a portal to other commercial websites.

We studied a selection of French and English tourism destination websites. We were particularly interested in the effects of culture on the processes and outcomes of website design. These two countries differ in their culture, and culture might have an impact on website quality (WQS). Among studies that analysed companies' characteristics and their impact on website content and design, culture is one of the most widely studied variables. Many studies used the frameworks of Hofstede and Hall (Hofstede, 1991; Hall, 1976; Hall \& Hall, 1990) on cultural differences as a basis of comparison between organisations' websites (Usunier, Roulin, and Ivens, 2009). These studies highlighted that culture can have a significant impact on website content (Singh, Zhao and Hul, 2005), design (Wang, Wei, and Guo, 2012) or both (Usunier, Roulin, and Ivens, 2009). Regarding the specific context of tourism, little is known on the impact of culture on website design and content. The topic is a particularly interesting one because of the inter- and intra-organisational approach to tourism destination website design.

We formulated the following research questions:

1. What are the city-brand associations presented in tourism destination marketing organisations' websites?

2. To what extent are the publicly expressed tourism goals of a town consistent with the brand associations presented on its website?

3. Does culture have an influence on any disparity between the aims of a website promoting a tourism destination brand and its execution?

Tourism destination websites are the result of an active creation process in which cities' officials, webmasters and tourism office managers are typically involved. These co-create the website expecting that the resulting website receives evaluations from users which are consistent with stakeholders' objectives. A gap has often been noted in other industries between what the owners of a website expect and what actually appears on the website (Evans and Smith, 2004). Among other factors, culture might influence the consistency between website activities and officers' strategies, and it has been noted that web officers might bias the way that design objectives are implemented (Gillentine, 2003).

This study seeks to identify the causes and extent of such disparity between the aims and the reality of tourism destination websites.

\section{METHODOLOGY}

This research analyses the brand messages communicated by websites of a sample of tourism offices for French and English seaside tourism destinations. Our method combined two approaches. Firstly, we examined the specific communicated images. Secondly, interviews with officials of these cities compared the communicated image to the desired one.

Semantic exploration issues: Three themes are in general linked to functionality aspects that webmasters need to take into consideration when designing or evaluating a website. Firstly, the website's content needs to be 
separated and organized into categories related to key words. Consequently, the search effort of the visitor will be easier. Then all content pages should be linked to others in a coherent way to help visitors to go further in their search for information. Finally, the information must be easy to find and the navigation easy.

A previously validated tool - WEFTQDA - has been used to measure place brand elements in city tourism websites. The author (Blumrodt, 2011) explored the use of this software. We employed this software to examine whether or not the identification of place brand elements using a process referred to as French Sphinx Lexica ${ }^{\circledR}$ positively correlates to the findings of the exploratory analysis ( $c f$. http://www.sphinxsurvey.com/).

Exploratory Analysis: In order to collect qualitative data regarding the expectations of city officials, the Mayors' offices of a sample of tourist cities were contacted and interviews were set up by phone or in-person. The interviews were guided by a semi-structured questionnaire. Similar questions were put to the different elected officials responsible for tourism. We measured the intended brand elements. This generated a comparative analysis between the real/communicated brand elements which have been put in place via the tourism office or/and the webmasters (tourism office website) and the desired brand image (city officials' expectations). Interviews with officials brought to light their expectations more precisely. These interviews were conducted by English or French native speakers. To be as accurate as possible, we recorded and transcribed these interviews. Analysis of the interviews was carried out using nVivo.

City Selection: The sample of cases was selected using a purposive sampling method. The definition of our sample and selection of cases was derived from several principles noted in the literature, notably the need to identify best practices and our interest in evaluating the competitiveness of French and English seaside destinations. To try and control for differences in type of tourism, our sample frame comprised only seaside towns and their websites. We selected eleven well known French seaside tourism destinations. The cities are located on the Atlantic coast in the southwest of France. As a comparison, we chose four English south coast cities.

The analytical strategy combined two methods. We first followed the well-established qualitative interpretative methodological precedents and then drew upon the more quantitative methodology associated with "interactionist sociology", a generic micro-sociological paradigm integrating aspects of phenomenology, ethnomethodology, symbolic interactionism and social constructionism, which has a worldwide following today.

\section{FINDINGS}

We found that cities with a similar environment communicate elements of their natural settings as well as other brand elements but the communicated image often does not correspond to the desired brand image.

The interviews and web analysis generated multiple items corresponding to the different brand categories and factors. Items were recognized when they appeared in headings, and, a minimum of once in sentences in websites' content. These items became evident during the analysis of literature, interviews and first visits of websites.

The product related attributes of seaside tourism destinations were related to three main factors, the natural and architectural heritage, as well as existing facilities. In Figure 1, the natural heritage is reflected by four items (nature, beach, country and sea), the architectural by three (architecture, museum churches), and the facilities by eleven (leisure, activities, sport, golf, tennis, windsurfing/surfing, camping, hotel, restaurant, shopping, boat). 


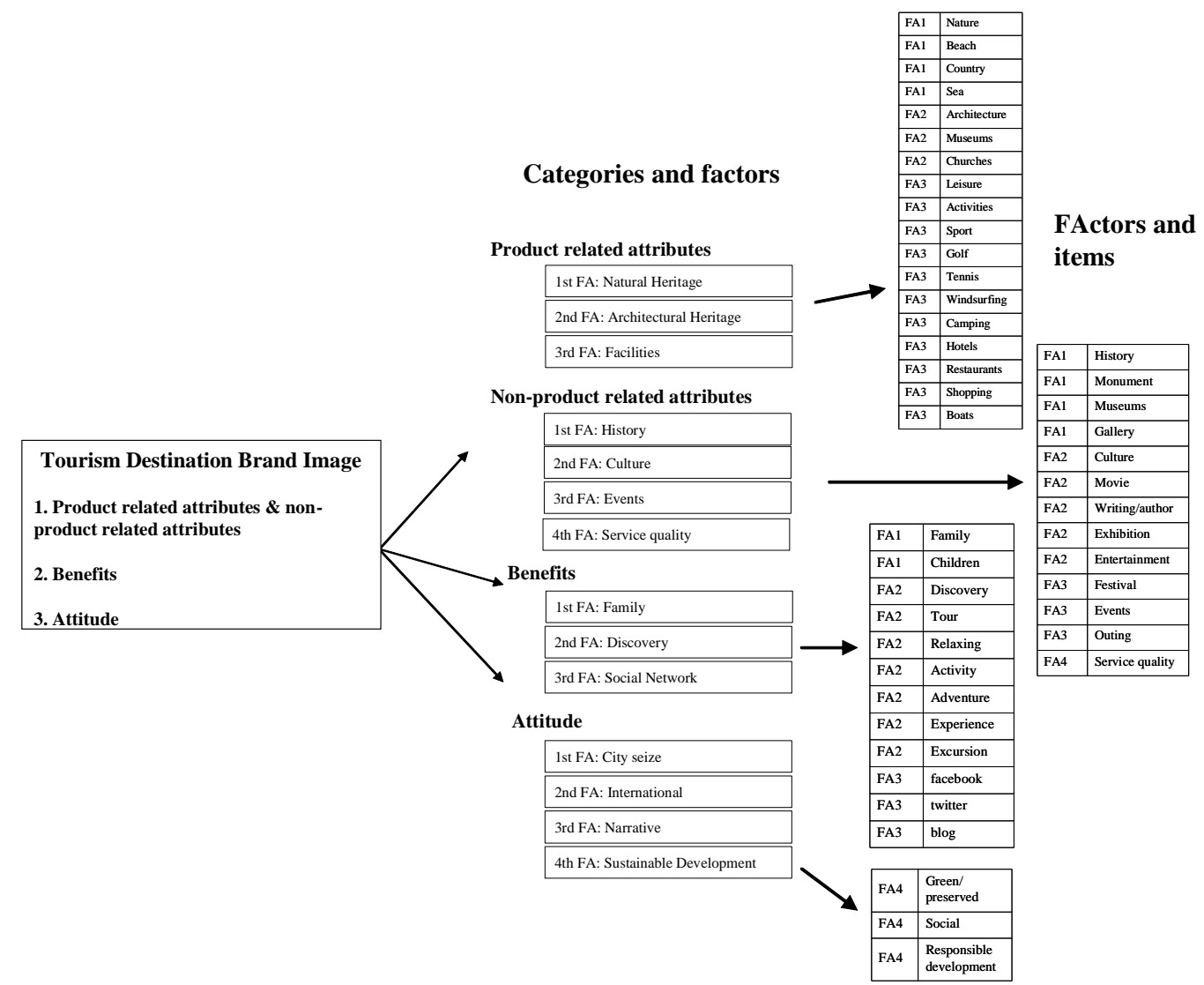

Figure 1: Concept of Tourism Destination Brand Image

The non-product related attributes are founded on four factors with their different items; brand benefits on three factors. Brand attitude factors were based on adjectives which do not figure on the websites (city size and international). Others could not be recognized as an item but were linked to writing style skills (narrative). If the 1st and 2nd factors were generated during the next step of analysis, the 3rd factor was linked to researchers' overall assessment of the writing style. The last factor of this category was linked to sustainable development, therefore items were recognized ("green and/ or preserved, social, responsible development").

In this first presentation, city-brand associations on websites were identified for seaside tourism destinations. The next step counted items. For input, advertisements were formally coded by reference to the 46 coded items. The results of our counting method were regrouped into factors, the brand elements ( $c f$. Table 1: FA). 
Table 1: Frequency Of Items In Tourism Destination Image

\begin{tabular}{|c|c|c|c|c|c|c|c|c|c|c|c|c|c|c|c|}
\hline $\begin{array}{c}\text { FA and } \\
\text { items }\end{array}$ & Arcachon & Biarritz & Carnac & Deauville & Dinard & Hossegor & $\begin{array}{c}\text { La } \\
\text { Rochelle }\end{array}$ & Quiberon & \begin{tabular}{|c|} 
Saint \\
Jean de \\
Luz \\
\end{tabular} & $\begin{array}{l}\text { Saint } \\
\text { Malo }\end{array}$ & $\begin{array}{l}\text { St. Pierre } \\
\text { d'Oléron }\end{array}$ & $\begin{array}{c}\text { Bournem } \\
\text { outh }\end{array}$ & Plymouth & Poole & Sidmouth \\
\hline $\begin{array}{l}\text { Natural } \\
\text { Heritage }\end{array}$ & 60 & 11 & 47 & 51 & 6 & 11 & 50 & 99 & 13 & 46 & 40 & 6 & 10 & 25 & 10 \\
\hline \begin{tabular}{|l|} 
Architecture \\
Heritage \\
\end{tabular} & 3 & 4 & 9 & 2 & 0 & 0 & 13 & 6 & 0 & 6 & 10 & 1 & 2 & 9 & 11 \\
\hline Facilities & 49 & 27 & 35 & 56 & 8 & 27 & 53 & 63 & 24 & 55 & 72 & 12 & 19 & 54 & 28 \\
\hline History & 10 & 7 & 7 & 4 & 0 & 0 & 18 & 7 & 2 & 8 & 14 & 6 & 5 & 11 & 5 \\
\hline Culture & 11 & 10 & 15 & 25 & 1 & 1 & 9 & 9 & 4 & 28 & 19 & 4 & 10 & 6 & 6 \\
\hline Events & 2 & 3 & 1 & 14 & o & 2 & 5 & 7 & 3 & 9 & 5 & 3 & 8 & 16 & 7 \\
\hline Quality & 2 & 4 & 2 & 8 & 0 & 2 & 4 & 6 & $\mathbf{0}$ & $\mathbf{0}$ & 4 & 1 & 1 & 1 & 2 \\
\hline Family & 9 & $\mathbf{0}$ & 9 & 3 & 3 & 2 & 9 & 22 & o & 6 & 11 & 4 & 4 & 16 & 3 \\
\hline Discovery & 5 & 5 & 9 & 11 & 5 & 4 & 9 & 18 & 4 & 18 & 12 & 4 & 5 & 36 & 9 \\
\hline Social Netw. & 1 & $\mathbf{0}$ & $\mathbf{0}$ & 1 & 2 & $\mathbf{0}$ & 3 & 2 & $\mathbf{0}$ & 4 & $\mathbf{0}$ & 1 & $\mathbf{0}$ & $\mathbf{0}$ & $\mathbf{0}$ \\
\hline Sustainable & 7 & 6 & 3 & 7 & $\mathbf{0}$ & 1 & 5 & 3 & 1 & 3 & 3 & $\mathbf{0}$ & $\mathbf{0}$ & 5 & 2 \\
\hline Sum & 159 & 77 & 137 & 182 & 25 & 50 & 178 & 242 & 51 & 183 & 190 & 42 & 64 & 179 & 83 \\
\hline Mean & 14 & 7 & 12 & 17 & 2 & 5 & 16 & 22 & 5 & 17 & 17 & 4 & 6 & 16 & 8 \\
\hline Other means & 6 & 4 & 6 & 9 & 1 & 2 & 8 & 9 & 2 & 10 & 9 & 3 & 4 & 11 & 4 \\
\hline
\end{tabular}

Data analysis continued systematically, but the process of factoring cannot explain the complex processes which underlie particular significance that is allocated to a given message by individuals.

Natural aspects and the attractiveness of city tourism destinations are at the heart of brand image. This was observed from the initial approach. If we take other means as a basis of observation (other means excluding product related attributes), several tourism destinations also focused on other factors. Different elements appeared specifying their point of view concerning the city's brand image and the importance accorded to on-line communication. Tourism destinations were focussing on aspects other than just the city's and region's beauty. Interviews made these elements clear. Strategic brand elements were recognized during the interviews.

These are mentioned as corresponding factors - (left column in Table 1) - city column - cities' names are mentioned in the first line. If these elements feature as items on the city's website, the officials' perceptions of tourism destination brand image "fit" their website designed brand image. We do not present all tourism destinations in detail. 
Table 2: Officials' Perceptions Of Tourism Destination Brand Image

\begin{tabular}{|c|c|c|c|c|c|c|c|c|c|c|c|c|c|c|c|}
\hline Officials & \begin{tabular}{|l|} 
Arcachon \\
\end{tabular} & Biarritz & Carnac & $\begin{array}{l}\text { Deauville } \\
\end{array}$ & Dinard & Hossegor & La Rochelle & Aron & \begin{tabular}{|l|l} 
Saint Jean de \\
\end{tabular} & \begin{tabular}{|l|} 
Saint Malo \\
\end{tabular} & $\begin{array}{l}\text { St. Pierre } \\
\text { dio }\end{array}$ & \begin{tabular}{|l|} 
Bournemouth \\
\end{tabular} & Plymouth & Poole & Sidmouth \\
\hline Natural Heritage & 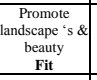 & & $\begin{array}{c}\text { Sea side } \\
\text { beauty } \\
\text { Fit } \\
\end{array}$ & & & & $\begin{array}{c}\text { Maritime wit } \\
\text { the marinan } \\
\text { commer } \\
\text { Fit }\end{array}$ & $\begin{array}{c}\text { Sea beau } \\
\text { Fit }\end{array}$ & & \begin{tabular}{|l|} 
Maritime \\
biotechnology \\
Fit
\end{tabular} & $\begin{array}{l}\text { lan } \\
\text { lacepe to } \\
\text { scover } \\
\text { Fit }\end{array}$ & & & $\begin{array}{c}\begin{array}{c}\text { Famous } \\
\text { beaches } \\
\text { Fit }<\boldsymbol{s}\end{array} \\
\end{array}$ & \\
\hline \begin{tabular}{|l} 
Architectural \\
Heritage \\
\end{tabular} & & & & & & & & & $\begin{array}{c}\text { Harmonony of } \\
\text { architecture } \\
\text { No Fit } \\
\end{array}$ & $\begin{array}{c}\begin{array}{c}\text { Historical } \\
\text { heritage } \\
\text { Fit }\end{array} \\
\end{array}$ & & & & & \\
\hline Facilities & $\begin{array}{c}\begin{array}{c}\text { Richness of } \\
\text { activities } \\
\text { Fit }\end{array} \\
\text { int }\end{array}$ & &  & 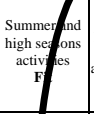 & & $\begin{array}{c}\text { Surf clientele } \\
\text { (surf suoptr) } \\
\text { Fit }\end{array}$ & & $\begin{array}{c}\begin{array}{c}\text { Well-being, } \\
\text { moving } \\
\text { (bicycle \& } \\
\text { equestrian } \\
\text { paths ste.) } \\
\text { Fit }\end{array} \\
\end{array}$ & 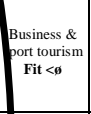 & $\begin{array}{c}S_{\text {Sports }} \\
\text { Fit }\end{array}$ & & \begin{tabular}{|c|} 
Best facilities \\
\& water sport \\
activitis of \\
other pports \\
Fit
\end{tabular} & 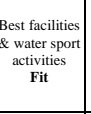 & 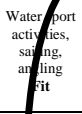 & \\
\hline History & & & & & & & & & & & & & & & \\
\hline Culture & & 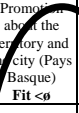 & & $\begin{array}{l}\text { licy } \\
\text { fit }\end{array}$ & & $\begin{array}{l}\text { Basaupe culut } \\
\text { No Fit }\end{array}$ &  & & 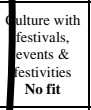 & $\begin{array}{c}\text { Literature, } \\
\text { wwititer } \\
\text { Fit }\end{array}$ & & & $\begin{array}{c}\begin{array}{c}\text { Activities } \\
\text { others then } \\
\text { seaside: } \\
\text { cultural } \\
\text { infrastructures } \\
\text { Fit<s }\end{array} \\
\end{array}$ & & \\
\hline Events & & $\begin{array}{l}\text { ntertainment } \\
\text { in the city } \\
\text { ivit<s }\end{array}$ & & & $\begin{array}{r}\text { Event dric } \\
\text { policy } \\
\text { No } \mathrm{Fil}\end{array}$ & $\begin{array}{c}\substack{\text { Sport events } \\
\text { No Fit }} \\
\text { Nat }\end{array}$ & & $\begin{array}{c}\text { Event diviven } \\
\text { Folicy (Breton } \\
\text { culture) } \\
\text { Fit }\end{array}$ & & $\begin{array}{c}\text { Event drive } \\
\text { policy } \\
\text { Fit }\end{array}$ & & & & & \\
\hline Quality & & 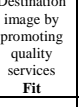 & & & & & $\begin{array}{r}\text { Quality } \\
\text { (well bo } \\
\text { Fit }\end{array}$ & & & $\begin{array}{l}\text { ality of lit } \\
\text { Fit }\end{array}$ & & & & & \\
\hline Family & $\begin{array}{l}\text { Seaside for old } \\
\& \text { young } \\
\text { Fit }\end{array}$ & & $\begin{array}{l}\text { al place } \\
\text { anily } \\
\text { Fit }\end{array}$ & 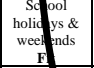 & & & & & $\begin{array}{l}\text { City of family } \\
\text { No Fit }\end{array}$ & & & & & & \\
\hline Discover & & & & & & & & & & $\begin{array}{c}\text { Discover } \\
\text { about Corsaire } \\
\text { Fit }\end{array}$ & $\begin{array}{l}\text { Accessible } \\
\text { island to } \\
\text { didover } \\
\text { init }\end{array}$ & & & & \\
\hline $\begin{array}{l}\text { Seize thousands of } \\
\text { habitants }\end{array}$ & $<15$ & $=30$ & $<5$ & $<5$ & $=10$ & $<5$ & $<80$ & $=5$ & $<15$ & $=50$ & $=5$ & $<170$ & $<150$ & $<260$ & $<20$ \\
\hline International & 3 & 3 & 2 & 18 & 2 & 13 & 13 & 1 & 13 & I1 & & - & - & - & \\
\hline \begin{tabular}{|l}
$\begin{array}{l}\text { Sustainable } \\
\text { Development }\end{array}$ \\
\end{tabular} & & & & & & & $\begin{array}{l}\text { Urran ecology } \\
\text { Fit }\end{array}$ & & & & 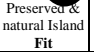 & & & & \\
\hline
\end{tabular}

Four examples of different desired and transmitted brand images illustrate the gap between web presentation and policies. The French town Deauville on the coast of Normandy - Pays d'Auge - has less than five thousand inhabitants. The town's beauty is known the world over as the "Planches de Deauville" where international stars of the American Film Festival have their seaside walk and give an American Touch to Normandy. The town focuses on beauty aspects, other aspects contribute to a larger image and the international website ( 8 foreign languages) is regularly updated in all languages. Dinard, with 10,000 habitants, has a quite similar desire for an international rank. The English Film Festival might be considered as a counterpart of the American Film Festival. The official we interviewed emphasised the importance of events, especially this festival, for this city. But no item makes this event visible on the website. Sporting activities are proposed (boating and other water based activities, fitness and wellness complexes and more non water based activities) by private organizations. They do not appear on the web. In terms of narration, the Dinard website has a more sophisticated writing style than Deauville's (Blumrodt, 2011) but the brand image does not fit. Hassegor's brand image quality is similar to Dinard's.

Bigger English seaside tourism destinations, such as Plymouth, started with a diversified brand image. They only communicate in English on their web. Even if English is a worldwide spoken language, there is no effort to be open to different linguistic cultures.

Different categories of city websites appeared. The first group (Dinard, Hossegor and Saint Jean de Luz) has a low score of items, especially for the mean of non-product related attributes. Their desired image does not fit the communicated image. The officials do not attribute the highest importance to the city brand image. The websites' management is delegated to webmasters. The second group (Bournemouth, Plymouth, and Sidmouth) are tourism destinations with a desired fitting and transmitted image. Like the first group, their brand image is not diversified. The sites are also managed by a webmaster. The third group (Poole, Deauville, and Saint Malo) contains the best performing websites, their brand images are diversified, and the desired image fits the transmitted image. The tourism office and the webmaster (Poole), or the city council, the tourism office, and a webmaster (Deauville and Saint Malo) take care of the website. Image and tourism are for those officials a priority. 


\section{DISCUSSION, IMPLICATIONS AND DIRECTIONS FOR FUTURE RESEARCH}

For four cities the desired brand image does not fit with the city's website ( $c f$. question 2: Does the elected officials' desired city-brand image fit the website image?). This can be explained by a lack of interest in attributed "importance of tourism" and "brand image associations" (Dinard and Hossegor) or by outsourced web design to webmasters (Carnac and Saint Jean de Luz). For many reasons officials' desired image might be distorted when it finally appears on the website ( $c f$. Figure 2: Model of WQS influencing factors).



Figure 2: Model Of WQS Influencing Factors

The Head of the tourism office is the executive manager and in charge of the website. A webmaster is often the interlocutor and intermediaries are asked to transcribe the policy developed by the elected officials. Differences occur in the image of a city, as portrayed on the website, and the image defined by tourism managers or officials. The success of on-line marketing efforts is dependent on the integration of the website into the organisation's overall marketing plan. The managers should have a clear idea of the desired and actual position of their own website in the market and a clear idea of how the website will be used to achieve the higher objectives of the organisation.

The question of expertise for commercial and governmental organizations starts with the establishment of a simple presence on the web. These sites become more functionally complex as the expertise of these organizations in the use of Internet technology increases and they incorporate more modules into these sites. If the expertise is assured, the decision makers and web designers have to be clear about essential image components. Our study made evident that elements appear which correspond to customers' expectations. They are almost all linked to natural heritage and facilities. But the developed model showed that tourism destinations communicate about other brand elements, then product related attributes and are leaving marketing communication which is only focussing on product related issues. Besides this, these tourism destinations balance product and non-product related attributes against each other, as well as brand benefits and attitudes.

The single product related approach is obsolete. Non-product related attributes influence and diversify images of the destination brand. This result is consistent with previous research on brand associations, claiming that brand associations have to focus on non-product related attributes to reach customers effectively (DeChernatony, 2001; De Chernatony and Segal-Horn, 2001).

We observed differences between French and English websites. Cultural dimensions may explain the differences of websites' content and design. Hofstede (1991) mentioned five cultural dimensions, namely Power Distance, Individualism vs Collectivism, Masculinity vs Feminity, Uncertainty avoidance and Long-term vs Shortterm orientation. France has a high degree of Power Distance, meaning that people, and especially less powerful members of the society, will be more likely to accept unequal distribution of power and high level of hierarchy. 
Therefore distance between less powerful and more powerful individuals is high and power is highly centralized. Regarding tourism destinations, because Great Britain has a low level of power distance, we can expect that communication between employees who perform specific tasks and managers who take decisions is easier and consequently consistency between strategies and actual outcomes should be higher than in France. We found a better fit between the actual versus the planned website and so better use of the Internet by English tourism destinations.

Both French and English societies have a high degree of individualism, with a higher degree for Great Britain. Therefore the interest of individuals will be more important than interest of the group. Communication will be widely encouraged and different opinions accepted. Therefore, we could expect to find places for interactions and feedback between officers and webmasters to obtain better fitting websites. We observed that the best French websites need the officials' involvement whereas English websites obtain high fitting scores without reference to political decision makers.

Whereas France is considered as a feminine country, in which quality of life and attention to others are more prevalent; Great Britain is a more masculine country with prevalent values such as competition, personal achievement, merit and success. Regarding website practices we observed that the sample of British tourism websites displayed more non-product related attributes whereas French websites underpin the natural beauty of the seaside.

France and Great Britain show significant differences regarding uncertainty avoidance. Uncertainty avoidance refers to the degree in which a society behaves towards unpredictable events. In France, people will usually refer to a clear context and background, and leave very little room for intuition and initiatives. Therefore the mean value of French tourism destinations is higher (134) compared to English websites (92). French websites are simpler and more "basic", with more items. We observed more innovative content and design in English websites, and a higher level of originality.

Finally, both France and Great Britain are short-term oriented countries, particularly Great Britain. This means that in both countries, people are attached to history and traditions. All websites display a history and, design and content show some similarities in terms of the general rules of tourism.

\section{AUTHOR INFORMATION}

Jens Blumrodt is Assistant Professor at the ESC Rennes, School of Business, France. He teaches and carries out research in the areas of sport and tourism management. He studied sport sciences at the University in Bielefeld (Germany) and holds a Doctorate in Sociology from the University of Rennes 2, Brittany (France). He is programme manager of the MSc. in Sports, Leisure and Tourism Management. His recent research is linked to strategic brand management and CSR issues as part of the ESC Research Centre for "Responsible Business".

Adrian Palmer is Professor of Marketing at ESC Rennes, France. His first career was in services marketing and management. Since joining academia, he has researched and published extensively on the subject of services buyer behaviour. His book "Principles of Services Marketing", now in its seventh edition, is widely used throughout the world to provide a grounding in the challenges and opportunities of marketing services. His research has been published in Journal of Marketing Management, European Journal of Marketing and Harvard Business Review.

\section{REFERENCES}

1. Anholt, S. (2006). Anholt City Brand Index - "How the World Views Its Cities", $2^{\text {nd }}$ ed., Global Market Insight, Bellevue, WA.

2. Anholt, S. (2010), Places - Identity, Image and Reputation. New York: Palgrave Macmillan.

3. Blumrodt, J. (2011). L'internet comme outil markéting communication distinctif pour vendre la côte française! In: Mansfield, C. \& Seligman, S. (2011). Narrative and the Built Heritage - Papers in Tourism Research, Saarbrücken: VDM, 86 - 115.

4. De Chernatony, L. (2001). A model for strategically building brands. Brand Management, 9(1) 32-44. 
5. De Chernatony, L., \& Segal-Horn, S. (2001). Building on services' characteristics to develop successful services brands. Journal of Marketing Management, 17(7-8) 645-669.

6. Evans, D.M., and Smith, A.C.T. (2004). The Internet and competitive advantage: A study of Australia's four premier professional sporting leagues. Sport Management Review, 7(1) 27-56.

7. Gillentine, A. (2003). Developing an Internet philosophy. Sport Marketing Quarterly, 12(1) 63-64.

8. Hall, E.T. (1976). Beyond Cultures. Oxford, England: Anchor.

9. Hall, E.T., \& Hall, M.R. (1990). Understanding Cultural Differences: Germans, French and Americans. Maine, USA: Intercultural Press Inc.

10. Hofstede, G. (1991). Cultures and Organizations: Software of the Mind. Maidenhead, UK: McGraw-Hill.

11. Singh, N., Zhao, H., \& Hu, X. (2005). Analyzing the cultural content of web sites. A cross-national comparison of China, India, Japan, and US. International Marketing Review, 22(2)129-146.

12. Usunier, J.C., Roulin, N., \& Ivens, B.S. (2009). Cultural, National, and Industry-Level Differences in B2B Web Site Design and Content. International Journal of Electronic Commerce, 14(2) 41-87.

13. Wang, Y.J., Wei, J., \& Guo, C. (2012). A multi-attribute comparison of U.S. and Chinese e-tail website design. International Journal of Business Research, 12(2) 183-189.

14. Zenker, S. (2011). How to catch a city? The concept and measurement of place brands. Journal of Place Management and Development, 4(1) 40-52. 


\section{NOTES}

